Aurelia Journal
(Authentic Research of Global Fisheries Application Journal)
E-ISSN: 2715-7113
e-mail: aureliajournal.pkpd@gmail.com

\title{
PENAMBAHAN PROBIOTIK MICROBACTER ALFAAFA 11 TERHADAP PERTUMBUHAN, KELANGSUNGAN HIDUP DAN FCR PADA BENIH IKAN PATIN SIAM (Pangasius hypophthalmus)
}

\section{THE ADDITION OF PROBIOTICS MICROBACTER ALFAAFA 11 ON GROWTH, SURVIVAL AND FCR AT SIAMASE CATFISH (Pangasius hypophthalmus)}

\author{
Hadi Supriyan ${ }^{1}$, Helmi Haris ${ }^{1}$, Rangga Bayu Kusuma Haris ${ }^{12^{*}}$ \\ Indah Anggraini Yusanti ${ }^{1}$, Sumantriyadi ${ }^{1}$ dan Arumwati $^{3}$ \\ 1 Fakultas Perikanan, Universitas PGRI Palembang, Indonesia \\ 2 Politeknik Kelautan dan Perikanan Dumai, Dumai, Indonesia \\ ${ }^{3}$ Satuan Pengawasan SDKP Palembang, Indonesia \\ *Korespondensi: ranggabkh@gmail.com (Rangga BKH) \\ Diterima 24 Februari - Disetujui 25 Maret 2020
}

\begin{abstract}
ABSTRAK. Penelitian ini bertujuan untuk Menganalisis pengaruh perbandingan pemberian pakan komersil dan probiotik terhadap pertumbuhan, kelangsungan hidup, FCR pada ikan patin siam (Pangasius hypophthalmus). Penelitian dilaksanakan di kampus C Fakultas Perikanan Universitas PGRI Palembang.Jalan Sakti Wiranata Kelurahan Srimulya Kecamatan Sematang Borang RT. 08 RW. 02 Palembang. Kegiatan penelitian dilakukan selama 28 hari. Ikan uji yang digunakan adalah benih ikan patin ukuran $4 \mathrm{~cm}$ dengan menggunakan kolam terpal sebanyak 12 buah yang berukuran $1 \mathrm{~m} \times 1 \mathrm{~m} \times 80 \mathrm{~m}$. Penelitian menggunakan Rancangan Acak Lengkap (RAL) terdiri 4 taraf perlakuan dengan 3 kali ulangan yaitu perlakuan P1 (Tanpa Probiotik $0 \mathrm{ml}$ ), P2 (Probiotik $5 \mathrm{ml}$ ), P3 (Probiotik $10 \mathrm{ml}$ ), dan P4 (Probiotik $15 \mathrm{ml}$ ). Hasil penelitian menunjukkan bahwa pertumbuhan berat rata-rata dan panjang benih ikan patin siam (Pangasius hypophthalmus) yang terbaik terdapat pada perlakuan P2 dengan berat 7,85 gram dan panjang $6,30 \mathrm{~cm}$. Untuk kelangsungan hidup ikan patin siam (Pangasius hypophtalmus) nilai tertinggi tertinggi terdapat pada perlakuan P2 sebesar 97,33\%, dan Konversi pakan nilai terendah terdapat pada perlakan P2 dengan rata-rata 0,65 . Serta secara keseluruhan dari perhitungan nilai pertumbuhan, kelangsungan hidup, dan FCR pada ikan patin siam (Pangasius hypophthalmus) perlakuan terbaik selama masa pemeliharaan terdapat pada perlakuan P2 yang dilihat dari pertumbuhan yang baik serta biaya pakan yang murah.
\end{abstract}

KATA KUNCl: Pakan komersil, probiotik,ikan patin siam (Pangasius hypophthalmus)

ABSTRACT. This study was aims to analyze the efeck of comparison of commercial feeding and probiotics to the growth, viability, FCR on Siamase catfish (Pangasius hypophthalmus). This study was conducted on campus c fakulty of fishery at university of PGRI Palembang. Jalan sakti subdistrict wiranata village Srimulya RT. 08 RW. 02 Palembang. This activiy is done for 28 days. Test fish used is siamese fish seeds size $4 \mathrm{~cm}$ with using tarpaulin pool as many as 12 pieces of size $1 \mathrm{~m} \times 1 \mathrm{~m} \times 80 \mathrm{~m}$. This study used completely randomized design (CRD) consists of 4 levels of treatment with 3 replications of treatment P1 (Without Probiotics $0 \mathrm{ml}$ ), P2 (Probiotics $5 \mathrm{ml}$ ), P3 (Probiotics $10 \mathrm{ml}$ ) and P4 (Probiotics $15 \mathrm{ml}$ ). Results of research showed that the growth of average weight and length of the seed Siamese catfish (Pangasius hypophthalmus) the best is in the treatment in P2 treatment with a weight of 7.85 grams and a length of 6.30. For the viability of Siamese catfish (Pangasius hypophtalmus) the highest value is in the treatment $P 2$ amount of 97.33 , and the lowest feed conversion rate is present in the treatmen P2with average 0.65. As well as overall of the calculation of growth, value, viability, and FCR on Siamese catfish (Pangasius hypophthalmus) best treatment during maintenance contained in the treatment of $P 2$ wich is seen from the good growth feed costs are cheap.

KEYWORDS: Commercial feed, probiotics, siamase catfish (Pangasius hypophthalmus). 


\section{Pendahuluan}

Ikan Patin Siam (Pangasius hypophthalmus) adalah salah satu jenis ikan air tawar yang paling banyak dikonsumsi oleh masyarakat Indonesia karena ikan Patin Siam (Pangasius hypophthalmus) ini memiliki banyak kandungan vitamin dan mineral yang sangat bermanfaat bagi kesehatan tubuh. Oleh karena itu, pembudidayaan ikan patin harus dilakukan secara intensif menggunakan pakan buatan secara komersil, upaya untuk meningkatkan laju pertumbuhan ikan tersebut (Kordi, 2010). Dalam proses budidaya, pakan merupakan salah satu faktor terpenting dalam budidaya yang berpengaruh terhadap partumbuhan dan kelangsungan hidup ikan yang akan dibudidaya. Pakan pada suatu proses budidaya membutuhkan 60-70 \% dari biaya produksi yang dikeluarkan oleh pembudidaya, agar pakan tersebut bisa bekerja secara optimal dan menghasilkan bobot ikan yang lebih berkualitas perlu suatu asupan yang tercampur pada pakan. Salah satu alternatif yang bisa ditempuh adalah penggunaan probiotik dalam pakan, dengan harapan probiotik tersebut dapat terbawa ke dalam saluran pencernaan dan bermanfaat dalam mengatur lingkungan mikroba pada usus, menghalangi mikroorganisme pathogen dengan melepas enzim-enzim yang membantu proses pencernaan makanan (Sahwan, 2004).

Menurut Artarizqi (2012), probiotik Microbacter alfaafa 11 adalah super decomposer yang mampu merombak rantai organik dengan cepat pada bahan pakan ternak, pupuk, bahan pangan, pembuat biotanol, peningkatan produksi pertanian dan ternak. Microbacter alfaafa 11 diambil dari nama tanaman Alfalfa (Medicago sativa) daun dari tanaman ini mengandung protein tinggi dan berbagai nutrisi, selain itu akar Alfaafa juga mengeluarkan sinyal yang dapat menarik bakteri Rhizobium sp, selain itu Microbacter alfaafa 11 memiliki beberapa jenis bakteri yaitu bakteri pencerna selulosa, bakteri pencerna hemiselulosa, bakteri pencerna pati, bakteri pencerna gula, dan bakteri pencerna protein. Microbacter alfaafa terdiri dari bakteri Rhizobium sp yang kemudian dipadukan dengan berbagai bakteri yang diambil dari rumen sapi dengan kolaborasi beberapa bakteri ini maka menjadikan Microbacter alfaafa 11 sebagai probiotik yang baik untuk pakan sehingga pemanfaatan probiotik Microbacter alfaafa11 dapat membantu pembudidaya dalam meningkatkan produksi ikan dan menekan biaya pakan (Artarizqi, 2012). Tetapi penelitian yang menggunakan probiotik pada ikan Patin Siam (Pangasius hypophthalmus) masih sangat terbatas terutama untuk meningkatkan pertumbuhan, kelangsungan hidup dan efisiensi pakan ikan Patin Siam (Pangasius hypophthalmus). Banyaknya spesies ikan budidaya memiliki kebiasaan makan yang berbeda-beda serta kemampuan memproduksi enzim seperti enzim pencernaan protease, lipase, dan amilase, maka perlu dikaji terkait dengan efektivitas probiotik komersil tersebut. Salah satu probiotik yang dapat dimanfaatkan pada ikan yaitu Mikrobater alfafa 11. Penelitian ini bertujuan untuk mengetahui pertumbuhan benih ikan benih Patin Siam (Pangasiushypophthalmus), mengetahui kelagsunan hidup benih ikan Patin Siam (Pangasiushypophthalmus), dan mengetahui FCR benih ikan Patin Siam (Pangasiushypophthalmus).

\section{Bahan dan Metode}

\subsection{Alat dan Bahan Penelitian}

Bahan yang akan digunakan pada penelitian ini disajikan pada Tabel 1.

\section{Tabel 1. Bahan yang digunakan pada Penelitian}

\begin{tabular}{cll}
\hline No & Bahan penelitian & \multicolumn{1}{c}{ Spesifikasi } \\
\hline 1 & Ikan Patin Siam & Benih yang digunakan berukuran 4 cm dengan harga Rp. 300/ ekor ikan, \\
2 & Probiotik MA 11 & Probiotik yang digunakan berbentuk cair \\
3 & Pakan komersil & Pakan yang digunakan berupa pelet \\
\hline
\end{tabular}

Alat yang akan digunakan pada penelitian ini disajikan pada Tabel 2. 
Tabel 2. Alat yang akan digunakan pada Penelitian

\begin{tabular}{clll}
\hline No & \multicolumn{1}{c}{ Alat } & \multicolumn{1}{c}{ Spesifikasi } & \multicolumn{1}{c}{ Kegunaan } \\
\hline 1 & Kolam terpal & $1 \mathrm{~m} \times 1 \mathrm{~m} \times 80 \mathrm{~cm}$ & Tempat pemeliharaan ikan \\
2 & pH-meter & Ketelitian pH 1-14 & Alat pengukur kualitas air \\
3 & Termometer & Ketelitian $1 \mathrm{C}$ & Alat pengukur kualitas air \\
4 & Timbangan analitik & Ketelitian $0,001 \mathrm{gr}$ & Menimbang beratikan \\
5 & Mistar ukur & $1 \mathrm{~mm}$ & Mengukur panjang ikan \\
6 & Ember & 1 buah & Wadah ikan sampling \\
7 & Scopnet & 1 buah & Mengambil ikan \\
8 & Selang & 1 buah & Untuk membersihkankolam \\
9 & Baskom & 4 buah & Wadah pakan \\
10 & Botol semprot & 1 buah & Untuk penyemprotan pakan \\
11 & Paranet & $4 \mathrm{~m} \mathrm{x} 7 \mathrm{~m}$ & Untuk atap kolam terpal \\
12 & Titrasi & $0,025 \mathrm{~N} \mathrm{Na2s203}$ & Untuk mengukur DO \\
13 & Spektrofotometer & $400-700$, Indonesia & Untuk mengukur Amonia \\
\hline
\end{tabular}

Penelitian ini telah dilaksanakan di Kampus C Fakultas Perikanan Universitas PGRI Palembang yang beralamat JL. Sakti Wiranata Kel. Srimulya Kec. Sematang Borang Rt. 08 Rw. 02 Palembang. Ikan uji yang digunakan sebanyak 300 ekor dengan masing-masing kolam berisi 25 ekor benih ikan Patin Siam. Penelitian ini menggunakan metode eksperimen dengan Rancangan Acak Lengkap dengan 4 taraf perlakuan dan diulang sebanyak 3 kali, (penentuan dosis yang digunakan mengacu pada penelitian Abdulah, 2007) :

$\mathrm{P}_{1}=$ Probiotik $0 \mathrm{ml} / \mathrm{kg}$ Pakan

$\mathrm{P}_{2}=$ Probiotik $5 \mathrm{ml} / \mathrm{kg}$ Pakan

$\mathrm{P}_{3}=$ Probiotik $10 \mathrm{ml} / \mathrm{kg}$ Pakan

$\mathrm{P}_{4}=$ Probiotik $15 \mathrm{ml} / \mathrm{kg}$ Pakan

\subsection{Analisis Data}

a. Pertumbuhan Berat dan Panjang

Pertumbuhan diamati dengan mengukur panjang dan bobot ikan. Data diperoleh dengan melakukan pengamatan setiap 1 minggu sekali selama 28 hari, setiap pengamatan benih diambil sebanyak 10 ekor benih per wadah, pengamatan pertumbuhan panjang dan bobot adalah sebagai berikut :

1) Pertumbuhan Berat Mutlak

Menurut Effendie (1997) dalam Ahmadi (2012), pengamatan pertumbuhan berat ikan dilakukan setiap 7 hari sekali dengan menggunakan rumus laju pertumbuhan mutlak :

\section{$\mathrm{Wm}=\mathrm{Wt}-\mathrm{Wo}_{0}$}

Keterangan:

Wm : pertumbuhan berat rata-rata ikan (gr); Wt : pertumbuhan berat rata - rata pada akhir pemeliharaan (gr); Wo : pertumbuhan berat rata - rata pada awal pemeliharaan (gr)

2) Pertambahan Panjang Mutlak

Perhitungan pertumbuhan panjang ikan dilakukan setiap 7 hari sekali dengan menggunakan rumus dari Effendie (1997) dalam Ahmadi (2012), yaitu :

Keterangan :

$$
\mathrm{Pm}=\mathrm{Pt}-\mathrm{Po}
$$

$\mathrm{Pm}$ : pertambahan panjang rata-rata ikan (cm); Pt : pertambahan panjang rata-rata ikan pada akhir pemeliharaan (cm); Po : pertambahan panjang rata-rata ikan pada awal pemeliharaan $(\mathrm{cm})$ 
b. Kelangsungan Hidup

Pengamatan kelangsungan hidup ikan dilakukan dengan cara mengamati jumlah ikan yang masih hidup pada tiap kolam setiap hari.Perhitungan kelangsungan hidup (SR) mutlak menurut Effendie (1997) dalam Ahmadi (2012), adalah sebagai berikut :

$$
S R=\frac{N t}{N o} \times 100 \%
$$

Keterangan :

SR : persentase hidup (\%); Nt : jumlah benih yang hidup pada akhir pemeliharaan (ekor); No : jumlah benih yang ditebar pada awal penelitian (ekor)

\section{c. $\quad$ FCR (Feed Convention Ratio)}

Untuk mengetahui jumlah pakan yang digunakan selama penelitian dapat dihitung menggunakan rumus Effendi (1997) dalam Abdullah (2007) sebagai berikut :

$$
F C R \equiv \frac{F}{(W t+D)-W o} x 100 \%
$$

Keterangan :

F : Total pakan yang digunakan; Wt : Berat total akhir pemeliharaan; Wo : Berat total awal pemeliharaan; D : Berat total ikan mati / mortalitas

d. Pengamatan Kualitas Air

Parameter kualitas air yang diamati adalah suhu, pH, oksigen terlarut (DO) dan amonia. Data hasil pengamatan yang diperoleh dianalisis secara statistika dengan menggunakan Analisa sidik ragam (ANSIRA), seperti pada Tabel 3.

\begin{tabular}{|c|c|c|c|c|c|c|}
\hline \multirow[t]{2}{*}{ SK } & \multirow[t]{2}{*}{ DB } & \multirow[t]{2}{*}{ JK } & \multirow[t]{2}{*}{ KT } & \multirow[t]{2}{*}{ F-hitung } & \multicolumn{2}{|c|}{ F-Tabel } \\
\hline & & & & & $5 \%$ & $1 \%$ \\
\hline Perlakuan & $t-1=V_{1}$ & JKP & $\mathrm{JKP} \mathrm{V}_{1}$ & KTP/KTG & & \\
\hline Galat & $(r t-1)-(t-1)=V_{2}$ & JKG & $\mathrm{JKG} / \mathrm{N}_{2}$ & & & \\
\hline Total & rt-1 & JKT & & & & \\
\hline
\end{tabular}

Tabel 3. Daftar Analisis Keragaman Rancangan Acak Lengkap (RAL)

Sumber : Hanafiah, (2011)

Jika F-hitung < F 5\% disebut tidak nyata sedangkan jika $\mathrm{F}$ hitung $>\mathrm{F} \mathrm{5 \%}$ disebut nyata dan jika nilai $\mathrm{F}$ hitung $>\mathrm{F} 1 \%$ disebut sangat nyata. Bila $\mathrm{F}$ hitungnya nyata atau sangat nyata, maka dilakukan uji lanjut. Uji lanjut yang digunakan jika nilai KK besar, (minimal $10 \%$ pada kondisi homogen atau minimal $20 \%$ pada kondisi heterogen), maka dilakukan uji lanjutan yang sebaiknya digunakan uji Duncan; Jika KK sedang, (antara 5-10\% pada kondisi homogen atau antara 10-20\% pada kondisi heterogen), maka dilakukan uji BNT (Beda Nyata Terkecil); dan jika KK kecil ( maksimal 5\% pada kondisi homogen atau maksimal 10\% pada kondisi heterogen), uji lanjutan yang sebaiknya dipakai adalah uji BNJ (Beda Nyata Jujur) (Hanafiah, 2011).

\section{Hasil dan Pembahasan}

\subsection{Pertumbuhan}

a. Pertumbuhan Berat Mutlak Ikan Patin Siam

Hasil pengamatan terhadap peningkatan pertumbuhan berat ikan Patin Siam (Pangasius hypophthalmus) pada masing-masing perlakuan dapat dilihat pada Gambar 1. 


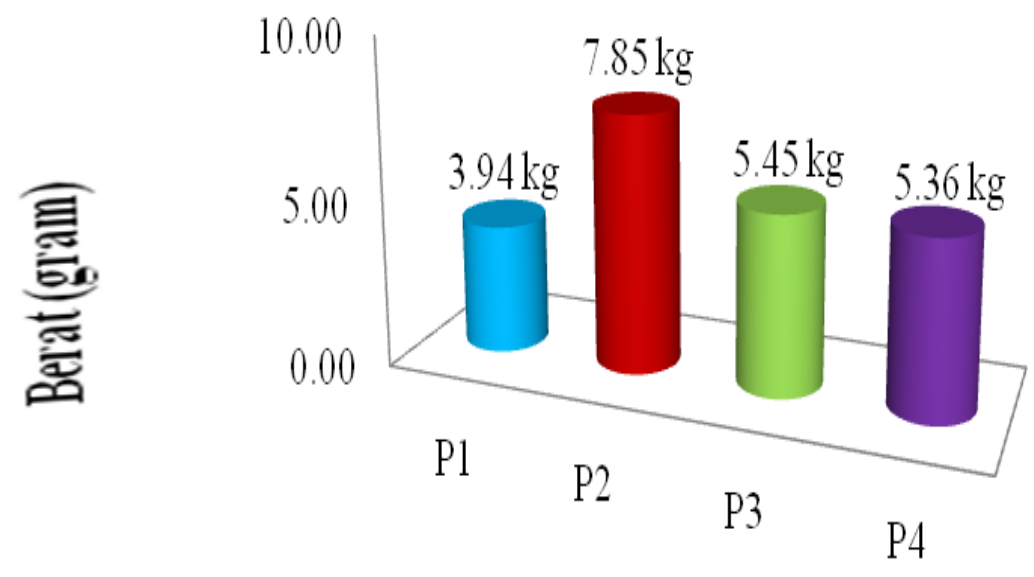

\section{Gambar 1. Grafik Pertambahan Berat Rerata Ikan Patin Siam (Pangasius hypophthalmus)}

Berdasarkan hasil dari Gambar 1 diatas menunjukkan nilai pertumbuhan berat yang terbaik yaitu perlakuan P2 (probiotik $5 \mathrm{ml}$ ) sebesar 7,85 gram, diikuti dengan perlakuan P3 sebesar 5,45 gram lalu perlakuan P4 sebesar 5,36 gram dan perlakuan P1 menghasilkan nilai yang terendah yaitu 3,94 gram. Berdasarkan pengamatan pertumbuhan berat terhadap pertumbuhan ikan Patin Siam (Pangasius hypopthhalmus) diperoleh hasil analisis sidik ragam (ANSIRA) kombinasi pakan pellet komersil dan probiotik pada pakan terhadap pertumbuhan, kelangsungan hidup, dan FCR pada benih Ikan Patin Siam (Pangasius hypophthalmus) dapat dilihat pada Tabel 4.

Tabel 4. Hasil Analisis ANSIRA Pertumbuhan Berat Ikan Patin Siam (Pangasius hypophthalmus)

\begin{tabular}{|c|c|c|c|c|c|c|}
\hline \multirow[t]{2}{*}{ SK } & \multirow[t]{2}{*}{ DB } & \multirow[t]{2}{*}{ JK } & \multirow[t]{2}{*}{ KT } & \multirow[t]{2}{*}{ Fhitung } & \multicolumn{2}{|l|}{ Ftabel } \\
\hline & & & & & $5 \%$ & $1 \%$ \\
\hline Perlakuan & 3 & 23.649 & 7.883 & $6.365^{*}$ & 4.07 & 7.59 \\
\hline Galat & 8 & 9.908 & 1.239 & & & \\
\hline Total & 11 & 33.557 & & & & \\
\hline
\end{tabular}

Ket: ${ }^{*}=$ Berpengaruh Nyata

$\mathrm{KK}=19.7001 \%$

Data hasil analisis sidik ragam pertumbuhan berat Ikan Patin Siam (Pangasius hypophthalmus) dengan perlakuan kombinasi pakan komersil dan probiotik terhadap pertumbuhan berat (Tabel 4) menunjukan hasil $F_{\text {hitung }}>F_{\text {tabel }}$ yaitu 6,365>4,07 pada taraf uji 5\% yang berarti menunjukkan bahwa kombinasi pakan pellet komersil dan probiotik berpengaruh nyata terhadap pertumbuhan berat ikan Patin Siam (Pangasius hypophthalmus) dengan nilai Koefisien Keragaman sebesar 19,7001\% maka dilakukan uji lanjut BNT yang dapat dilihat pada Tabel 5.

Berdasarkan (Tabel 5) hasil uji BNT pertumbuhan berat Ikan Patin Siam (Pangasius hypophthalmus) menunjukan bahwa perlakuan P2 berpengaruh nyata terhadap perlakuan P1, P3, dan $\mathrm{P} 4$, sedangkan perlakuan P1 berpengaruh tidak nyata terhadap perlakuan P3 dan P4. Pada perlakuan P1 (probiotik $0 \mathrm{ml}$ ) didapatkan hasil pertumbuhan berat terendah dibandingan dengan perlakuan lain yaitu dengan berat akhir 3,94 gram. Hal ini diduga untuk perlakuan P1 tidak ada keseimbangan pemberian pakan karena untuk meningkatkan pertumbuhan ikan membutuhkan asupan nutrisi yang seimbang. Menurut Wijayanti et al. (2014), menyatakan bahwa pakan yang terdapat dua sumber protein atau lebih akan memberikan pertumbuhan yang lebih baik dari pada ikan yang hanya diberi satu sumber protein. 
Tabel 5. Uji Lanjut BNT Pengaruh Penambahan Probiotik MA-11 pada Pakan Ikan terhadap Pertumbuhan Berat Benih Ikan Patin Siam (Pangasius hypophthalmus)

\begin{tabular}{ccc}
\hline Perlakuan & Rerata & Beda antar perlakuan \\
\hline $\mathrm{P}_{1}$ & 3.94 & $\mathrm{~A}$ \\
$\mathrm{P}_{4}$ & 5.36 & $\mathrm{~A}$ \\
$\mathrm{P}_{3}$ & 5.45 & $\mathrm{~A}$ \\
$\mathrm{P}_{2}$ & 7.85 & $\mathrm{~B}$ \\
\hline
\end{tabular}

$\mathrm{BNT}_{0,05}=2,095$

Keterangan: Angka diikuti huruf yang sama menunjukkan beda yang tidak nyata pada taraf uji $5 \%$.

Sedangkan perlakuan P2 (probiotik $5 \mathrm{ml}$ ) tingkat pertumbuhan beratnya tertinggi dari perlakuan lain yaitu dengan berat 7,85 gram. pada perlakuan P2 selama masa pemeliharaan jumlah pakan yang diberikan dapat direspon dengan baik oleh ikan dan tidak terdapat sisa-sisa pakan pada media pemeliharaan serta adanya keseimbangan antara kombinasi pakan pellet komersil dan probiotik yang memiliki kandungan asam amino yang lengkap dibandingkan dengan pakan komersil sehingga asam amino yang terdapat pada probiotik dapat melengkapi komponen asam amino yang kurang pada pakan komersil. Hal ini diperkuat oleh Yulisman \& Sasanti (2012), yang menyatakan bahwa keseimbangan komponen asam amino dan protein dalam pakan merupakan faktor utama dalam mempengaruhi pertumbuhan dan kesehatan ikan serta didalam kedua pakan tersebut terdapat 2 unsur protein pada masing-masing nilai protein yang terkandung pada pakan pellet komersil dan probiotik. Tingginya nilai pada perlakuan $\mathrm{P} 2$ juga didukung oleh nilai kualitas air yang sudah optimal dan memiliki nilai yang baik yaitu $\mathrm{pH}$ berkisar 6,8-7,4, suhu $27-31^{\circ} \mathrm{C}$, DO berkisar 2,70-3,67 dan amonia 0,08-1,19. Menurut Affandi et al. (2004), menyatakan bahwa tingkat pertumbuhan dan kelangsungan hidup ikan dipengaruhi oleh manajemen budidaya yang baik antara lain padat tebar, kualitas pakan, kualitas air, parasit atau penyakit.

Sedangkan untuk perlakuan P3 dan P4 masih kurangnya tingkat pertumbuhan, hal ini diduga jumlah pakan yang diberikan tidak semuanya termakan oleh ikan, terdapat sisa-sisa pakan media pemeliharaan sehingga pakan yang sudah ditelan didalam lambung sebagian pakan dimuntahkan kembali, maka dari itu pakan yang dikonsumsi tidak cukup untuk mendapatkan pertumbuhan yang optimal.

b. Pertumbuhan Panjang Ikan Patin Siam (Pangasius hypophthalmus)

Hasil pengamatan terhadap peningkatan pertumbuhan panjang ikan Patin Siam (Pangasius hypophthalmus) selama penelitian pada setiap perlakuan dapat dilihat pada Gambar 2.

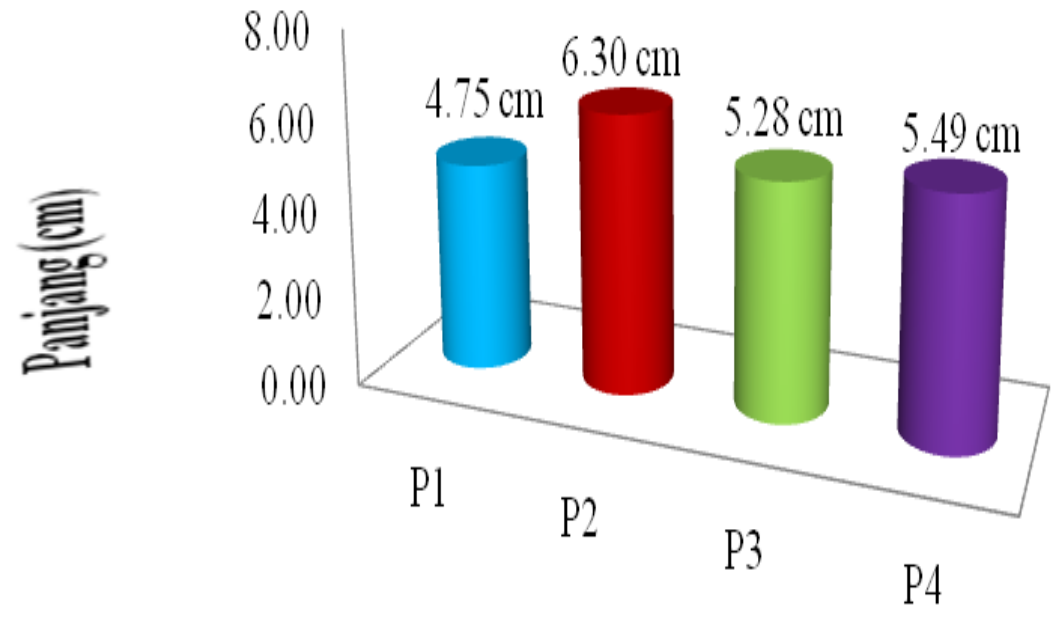

Gambar 2. Grafik Pertambahan Panjang Rata-rata Ikan Patin Siam (Pangasius hypophthalmus) 
Berdasarkan hasil dari Gambar 2 diatas menunjukkan nilai pertumbuhan panjang tertinggi terdapat pada perlakuan P2 sebesar $6,30 \mathrm{~cm}$, diikuti dengan perlakuan P4 sebesar $5,49 \mathrm{~cm}$ dan perlakuan P1 menghasilkan hasil yang terendah yaitu $4,75 \mathrm{~cm}$. Berdasarkan pengamatan pertumbuhan panjang ikan Patin Siam (Pangasius hypophthalmus) diperoleh hasil Analisis ANSIRA perlakuan kombinasi pakan pellet komersil dan probiotik terhadap pertumbuhan panjang Ikan Patin Siam dapat dilihat pada Tabel 6.

Tabel 6. Hasil ANSIRA Pertumbuhan Panjang Ikan Patin Siam (Pangasius hypophthalmus)

\begin{tabular}{ccccccc}
\hline SK & DB & JK & KT & Fhitung & \multicolumn{2}{c}{ Ftabel } \\
\cline { 5 - 7 } & & & & & $\mathbf{5 \%}$ & $\mathbf{1 \%}$ \\
\hline Perlakuan & 3 & 3.749 & 1.250 & $7.254^{*}$ & 4.07 & \\
Galat & 8 & 1.378 & 0.172 & & & \\
\hline Total & 11 & 5.128 & & & & \\
\hline Ket $:{ }^{*}=$ Berpengaruh Nyata & & & & & \\
KK $=7,60917 \%$ & & & & & &
\end{tabular}

Data hasil analisis ANSIRA pertumbuhan panjang Ikan Patin Siam (Pangasius hypophthalmus) dengan perlakuan Kombinasi pakan komersil dan probiotik pada (Tabel 6) menunjukan $F_{\text {hitung }}>F_{\text {tabel }}$ $5 \%$ dimana $7.254>4,07$, yang artinya berpengaruh nyata antar perlakuan kombinasi pakan pellet komersil dan probiotik dengan nilai Koefisien Keragaman sebesar 7,60917\% maka dilakukan uji lanjut BNT yang dapat dilihat pada Tabel 7.

Tabel 7. Uji Lanjut BNT Pengaruh Penambahan Probiotik MA-11 pada Pakan Ikan terhadap Pertumbuhan Panjang Mutlak Benih Ikan Patin Siam (Pangasius hypophthalmus)

Perlakuan

$P_{1}$

$P_{3}$

$\mathrm{P}_{4}$

$\mathrm{P}_{2}$
Rerata

4.75

5.28

5.49

6.30
Beda antar perlakuan
A
A
A
B

$\mathrm{BNT}_{0,05}=\mathbf{0 , 7 8 2}$

Keterangan: Angka diikuti huruf yang sama menunjukkan beda yang tidak nyata pada taraf uji $5 \%$.

Berdasarkan pada Tabel 7. bahwa pemberian probiotik pada dosis $5 \mathrm{ml}$ (P2) menghasilkan pertambahan panjang ikan sebesar $6,30 \mathrm{~cm}$ yang berpengaruh nyata terhadap perlakuan $\mathrm{P} 1, \mathrm{P} 3$, dan P4, sedangkan perlakuan P1 berpengaruh tidak nyata terhadap perlakuan P3 dan P4. Berdasarkan hasil pengamatan pertambahan panjang Ikan Patin Siam (Pangasius hypophthalmus) pada Gambar 5 menunjukkan nilai yang terendah terdapat pada perlakuan P3 (probiotik $10 \mathrm{ml}$ ) yaitu 5,28 cm dan perlakuan P4 (probiotik $15 \mathrm{ml}$ ) yaitu $5,49 \mathrm{~cm}$. hal ini dikarenakan pakan yang diberikan pada perlakuan P3 dan P4 banyak mengandung probiotik, diduga dengan banyaknya kandungan probiotik tersebut memacu benih ikan untuk memakan pakan yang diberikan, disamping itu dengan kondisi pakan yang seperti ini, akan mudah diserap dan dicerna serta diuraikan oleh ikan patin sehingga akan mempengaruhi pertumbuhan panjang. Menurut Mujiman (2002), laju pertumbuhan dipengaruri oleh suhu air, persedian pakan, komposisi makanan, ruang gerak, persediaan oksigen dan hasil buangan metabolisme.

Pertumbuhan panjang terendah yaitu terdapat pada perlakuan P1 (probiotik $0 \mathrm{ml}$ ) yaitu $4,75 \mathrm{~cm}$. Hal ini diduga pakan yang dikonsumsi oleh ikan tidak dapat di respon dengan baik oleh ikan. Menurut Wijayanti et al. (2014), menyatakan bahwa pertumbuhan merupakan proses hayati yang akan berlangsung didalam tubuh ikan, pertumbuhan akan terjadi apabila jumlah makanan yang dikonsumsi ikan melebihi kebutuhan pemeliharaan tubuh. Hal ini juga diperkuat oleh Mutjiman (2002), menyatakan bahwa jumlah makanan dan kandungan gizi yang seimbang dengan kebutuhan ikan merupakan hal 
yang penting bagi kehidupan ikan untuk melakukan metabolisme dan pertumbuhan. Sedangkan pertumbuhan panjang rata-rata tertinggi pada perlakuan P2 (probiotik $5 \mathrm{ml}$ ) yaitu 6.30 , menunjukkan perbedan yang siknifikan dengan perlakuan P1 (probiotik $0 \mathrm{ml}$ ). Hal ini diduga karena jumlah probiotik yang masuk kedalam saluran pencernaan benih ikan meningkat, sejalan dengan kandungan probiotik yang diberikan dan mengsekresikan enzim-enzim pencernaan serta meningkatkan daya cerna ikan. Hal ini sejalan dengan penelitian Mulyadi (2011), melaporkan bahwa laju pertumbuhan meningkat pada benih ikan Patin Siam (Pangasius hypoptalmus) akibat penambahan probiotik yang mengandung bakteri Lactobacillus pada pakan. Hal ini sejalan dengan pernyataan yang dikemukakan oleh Haryanti et al. (2002) bahwa selain meningkatkan daya cerna dan sistem imun ikan, probiotik juga berperan dalam meningkatkan nafsu makan ikan yang berakibat pada naiknya laju pertumbuhan ikan.

\subsection{Kelangsungan Hidup}

Hasil pengamatan kelangsungan hidup ikan Patin Siam (Pangasius hypophthalmus) pada masing-masing perlakuan disajikan secara lengkap pada Gambar 3.

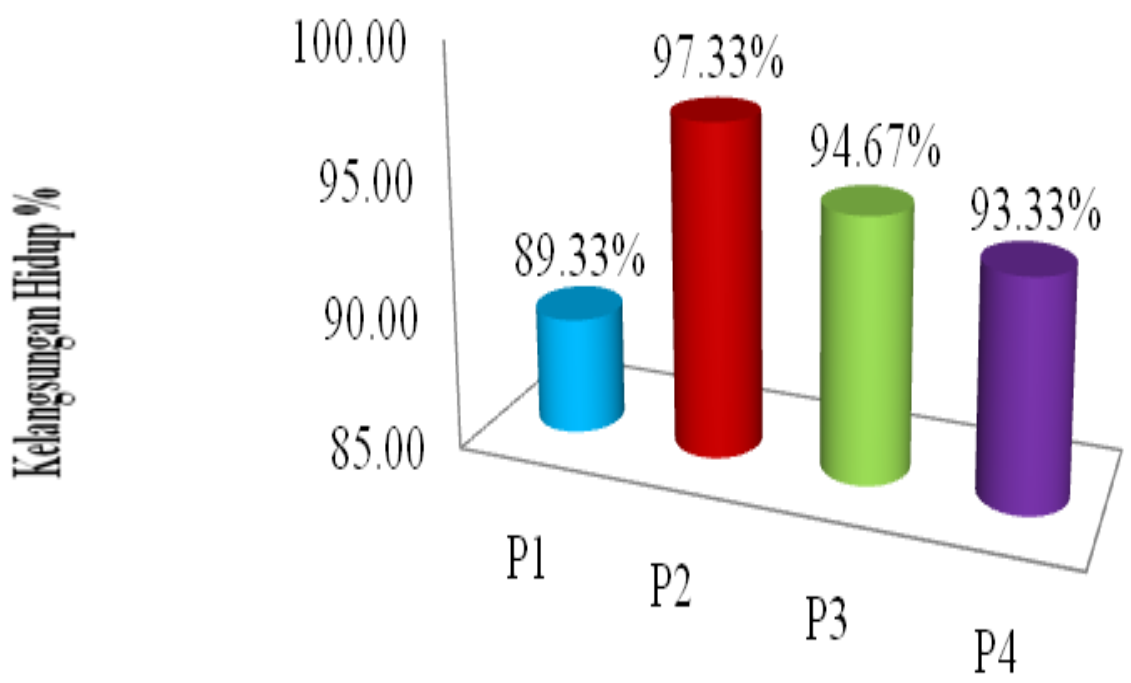

\section{Gambar 3. Rerata Kelangsungan Hidup (\%) Benih Ikan Patin Siam (Pangasius hypophthalmus)}

Berdasarkan pada Gambar 3 menunjukkan nilai kelangsungan hidup tertinggi terdapat pada perlakuan P2 yaitu 97,33\%, diikuti perlakuan P2 dengan rata-rata sebesar $94,67 \%$ dan perlakuan P4 sebesar $93,33 \%$. Sedangkan nilai kelangsungan hidup terendah terdapat pada perlakuan P1 dengan nilai rata-rata sebesar $89,33 \%$. Berdasarkan perhitungan kelangsungan hidup Ikan Patin siam (Pangasius hypophtalmus) diperoleh hasil data Analisis ANSIRA kombinasi pakan komersil dan probiotik terhadap kelangsungan hidup Ikan Patin Siam dapat dilihat pada Tabel 8.

Tabel 8. Hasil ANSIRA Kelangsungan Hidup Ikan Patin Siam (Pangassius hypophthalmus)

\begin{tabular}{ccccccc}
\hline SK & DB & JK & KT & Fhitung & \multicolumn{2}{c}{ Ftabel } \\
\cline { 5 - 7 } & & & & & $\mathbf{5 \%}$ & $\mathbf{1 \%}$ \\
\hline Perlakuan & 3 & 100.000 & 33.333 & $1.562^{\text {tn }}$ & 4.07 & 7.59 \\
Galat & 8 & 170.667 & 21.333 & & & \\
Total & 11 & $\mathbf{2 7 0 . 6 6 7}$ & & & & \\
\hline
\end{tabular}

Ket: ${ }^{\mathrm{tn}}=$ Berpengaruh Tidak Nyata

$\mathrm{KK}=4,931106 \%$ 
Data hasil analisis ANSIRA kelangsungan hidup Ikan Patin Siam (Pangasius hypophthalmus) dengan perlakuan Kombinasi pakan komersil dan probiotik pada (Tabel 8) menunjukan $F_{\text {hitung }}<F_{\text {tabel }}$ $5 \%$ dimana $1,562<4,07$, yang artinya tidak berpengaruh nyata antar perlakuan kombinasi pakan komersil dan probiotik dengan nilai Koefisien Keragaman sebesar 4,931106\% maka tidak perlu dilakukan uji lanjut. Hasil dari tabulasi pada Gambar 3 menunjukkan bahwa perlakuan P2 (probiotik 5 $\mathrm{ml}$ ) menghasilkan nilai rerata kelangsungan hidup tertinggi yaitu $97,33 \%$, diikuti perlakuan P3 penggunaan probiotik $10 \mathrm{ml}$ sebesar $94,67 \%$, perlakuan P4 penggunaan probiotik $15 \mathrm{ml}$ sebesar 93,33 $\%$. Menurut Inggrit (2001) dalam Irianto, (2003), penambahan probiotik pada pakan dengan dosis yang tepat dapat mempengaruhi perbaikan sintasan dan mencegah virus atau bakteri negatif yang ada didalam kolam pemeliharaan agar tidak mudah menyerang sistem pencernaan ikan. Hal ini menjadikan, probiotik mulai menjalankan perannya dalam meningkatkan kesehatan pada ikan.

Pada perlakuan P1 tanpa penambahan probiotik dalam pakan (0 $\mathrm{ml} / \mathrm{kg}$ pakan) menunjukkan kelangsungan hidup terendah yaitu sebesar $89,33 \%$, rendahnya tingkat kelangsungan hidup benih ikan patin siam ini diduga karena kurangnya mikroorganisme atau bakteri positif yang hidup didalam tubuh benih ikan patin siam. Sehingga ikan mudah terserang penyakit dan bakteri patogen lebih mudah menyerang sistem imun yang mengakibatkan tingkat kematian (mortalitas) lebih besar dari perlakuan P2, P3 dan P4 yang menambahkan probiotik MA-11 pada pakan pellet. Tingkat kelangsungan hidup benih ikan Patin Siam (Pangasius hypophthalmus) dalam penelitian ini tergolong baik pada seluruh perlakuan karena nilai rerata tingkat kelangsungan hidup sebesar 97,33 \%. Berdasarkan SNI 016463.3.2002, dimana nilai rata-rata tingkat kelangsungan hidup ikan patin siam yang baik berkisar antara $70-80 \%$.

\subsection{Konversi Pakan}

Hasil pengamatan konversi pakan ikan Patin Siam (Pangasius hypophthalmus) pada masingmasing perlakuan disajikan secara lengkap pada Gambar 4.

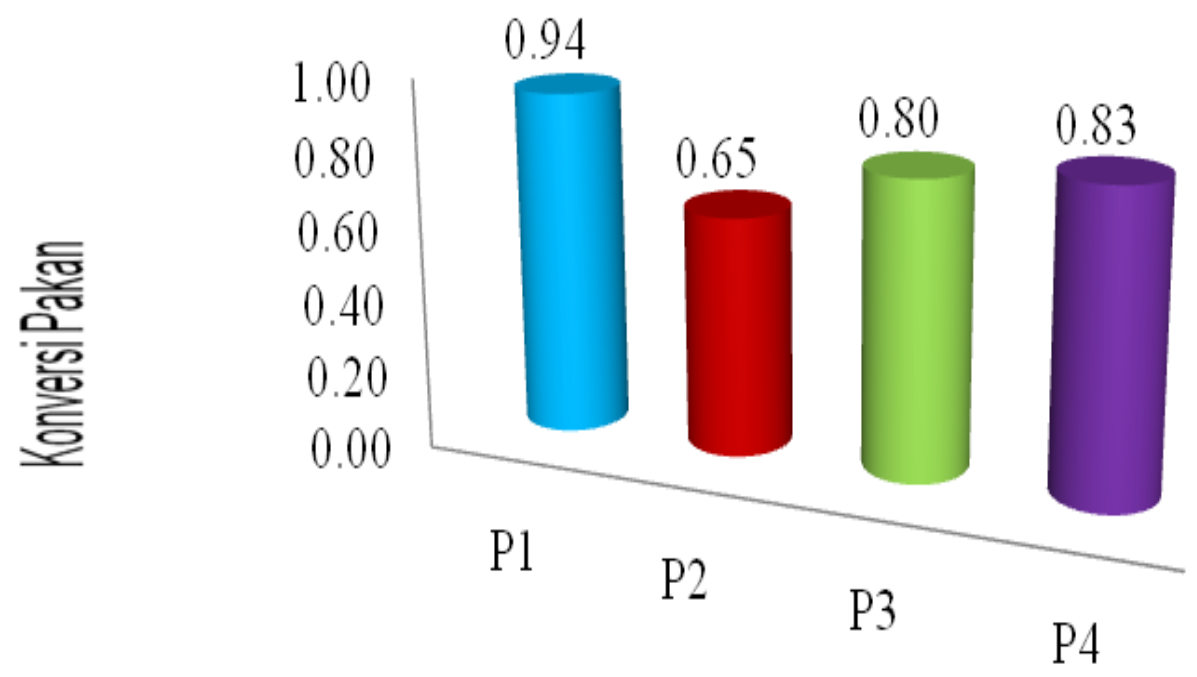

\section{Gambar 4. Rata-rata Konversi Pakan Benih Ikan Patin Siam (Pangasius hypophthalmus)}

Berdasarkan pada Gambar 4 menunjukkan bahwa perlakuan P1 menghasilkan konversi pakan tertinggi yaitu 0,94, diikuti Perlakuan P4 sebesar 0,83, perlakuan P3 sebesar 0,80, sedangkan nilai konversi pakan terendah terdapat pada perlakuan P2 dengan rata-rata sebesar 0,65. Berdasarkan perhitungan hasil dari konversi pakan ikan Patin Siam (Pangasius hypophthalmus) diperoleh hasil data analisis ANSIRA Pengaruh kombinasi pakan komersil dan probiotik terhadap konversi pakan Ikan Patin Siam (Pangasius hypophthalmus)dapat dilihat pada Tabel $\mathbf{9}$. 
Aurelia Journal, Vol. 1 (2): 39-52

Tabel 9. Hasil ANSIRA Konversi Pakan Ikan Patin Siam (Pangasius hypophthalmus)

\begin{tabular}{ccccccc} 
SK & DB & JK & KT & Fhitung & \multicolumn{2}{c}{ Ftabel } \\
\cline { 6 - 7 } & & & & & $\mathbf{5 \%}$ & $\mathbf{1 \%}$ \\
\hline Perlakuan & 3 & 0.181 & 0.060 & $3.545^{\text {tn }}$ & 4.07 & 7.59 \\
Galat & 8 & 0.136 & 0.017 & & & \\
\hline Total & 11 & $\mathbf{0 . 3 1 8}$ & & & &
\end{tabular}

Ket: ${ }^{\mathrm{t}}=$ Berpengaruh Tidak Nyata

$\mathrm{KK}=3,89693 \%$

Hasil analisis ANSIRA konversi pakan Ikan Patin Siam (Pangasius hypophthalmus) dengan Perlakuan Kombinasi pakan komersil dan probiotik (Tabel 9) menunjukan $F_{\text {hitung }}<F_{\text {tabel }}$ taraf $5 \%$ dimana $3,545<4,07$ yang berarti bahwa menunjukkan berpengaruh tidak nyata antara perlakuan dimana perlakuan kombinasi pakan komersil dan probiotik tidak memberikan pengaruh terhadap konversi pakan Ikan Patin Siam (Pangasius hypophthalmus). Meskipun tidak berpengaruh secara nyata, konversi pakan pada masing-masing perlakuan memiliki perbedaan nilai dari setiap perlakuan yang menunjukkan perbedaan kualitas pakan yang digunakan. Menurut Effendi (2003), dimana faktor yang mempengaruhi konversi pakan antara lain yaitu umur, jenis, ukuran ikan, sifat genetis, bau dan daya tahan pakan di dalam air. Semakin rendah nilai konversi pakan, semakin sedikit yang dibutuhkan untuk menghasilkan $1 \mathrm{~kg}$ daging ikan. Artinya, semakin efisien pakan tersebut diubah menjadi daging. Hal ini juga diperkuat oleh Sunafik (2000), menyatakan bahwa pertumbuhan bobot badan ikan yang semakin besar pada tingkat konsumsi pakan yang sama akan menghasilkan nilai konversi yang semakin kecil sehingga semakin baik daya guna pakan.

Pada perlakuan P2 (probiotik $5 \mathrm{ml}$ ) menghasilkan nilai konversi pakan yang paling rendah dibandingkan dengan perlakuan lainnya yaitu 0,65 . Hal ini diduga pemberian pakan pada perlakuan P2 dapat dimanfaatkan dengan baik oleh ikan secara optimal, maka dari itu pakan yang diberikan pada ikan dapat diubah menjadi daging. Nilai konversi pakan dipengaruhi oleh beberapa faktor yaitu kualitas dan kuantitas pakan, jenis, dan ukuran ikan serta mutu air. Dari hasil penelitian dapat dilihat adanya perbedaan dari beberapa perlakuan. Hal ini sesuai dengan pernyataan Sari et al. (2015), menyatakan bahwa perbedaan konversi pakan dari setiap perlakuan memperlihatkan perbedaan kualitas pakan yang digunakan.sedangkan menurut Sunafik (2000), menyatakan bahwa semakin baik kualitas pakan maka konversi pakan yang dicapai semakin rendah, baik tidaknya kualitas pakan ditentukan oleh seimbang tidaknya zat nutrient pakan yang sesuai dengan kebutuhan ikan. Pada perlakuan P2 mampu memanfaatkan penggunaan pakan secara optimal yang diikuti dengan pertambahan berat yang lebih besar dibandingkan perlakuan lainnya. Hasil penelitian ini mendukung pernyataan Effendie (2003), menyatakan bahwa semakin kecil jumlah pakan yang digunakan untuk menghasilkan daging, maka semakin efisien pemberian makan tersebut.

\subsection{Hasil Uji Proksimat}

Hasil analisis proksimat merupakan pengujian pakan sebagai evaluasi mutu yang dihasilkan. Fungsi dari hasil analisa proksimat ialah untuk menghasilkan gambaran secara garis besar kandungan gizi dan memberikan penilaian umum dari pemanfaatan pakan yang di uji. Data hasil analisa pakan pellet $100 \%$ dan pencampuran probiotik pada pakan pellet disajikan pada Gambar 5 .

Berdasarkan hasil analisis proksimat pakan pellet yang dilakukan, diperoleh hasil kandungan karbohidrat, protein, kadar air, kadar abu, dan lemak. Hasil analisa proksimat pada pakan pellet yang belum di dicampur probiotik menunjukan kandungan karbohidrat $24,00 \%$, protein 35,24\%, kadar air $9,88 \%$, kadar abu $8,93 \%$, dan lemak 3,80\%. Sedangkan pada pakan pellet yang sudah di campur dengan probiotik $5 \mathrm{ml}$ (P2) menunjukan kandungan karbohidrat 21,03\%, protein 33,65\%, kadar air $18,81 \%$, kadar abu $8,78 \%$, dan lemak $2,77 \%$, selanjutnya pakan pellet yang dicampur dengan probiotik $10 \mathrm{ml}$ (P3) menunjukan karbohidrat 16,55\%, protein 31,44\%, kadar air 11,52 \%, kadar abu 
$8,68 \%$, dan lemak $4,18 \%$, dan pada pakan pellet yang dicampurkan dengan probiotik $15 \mathrm{ml}$ (P4) menunjukan karbohidrat $16,80 \%$, protein $31,21 \%$, kadar air $12,53 \%$, kadar abu 9,37 \%, dan lemak $3,02 \%$, Jadi hasil dari pemberian probiotik kedalam pakan dapat meningkatkan kadar air dan kadar abu, serta menurunkan kandungan nutrisi protein, lemak, dan karbohidrat. Berdasarkan hasil analisa uji proksimat menunjukkan bahwa karbohidrat mengalami penurunan setelah pakan diberi probiotik, sedangkan pada perlakuan P1 karbohidratnya lebih tinggi dibandingkan perlakuan lainnya. Hal ini dikarenakanperlakuan P1 tanpa penambahan probiotik pada pakan tidak terdapat bakteri pemecah karbohidrat seperti Bakteroids ammylophius, Triponema bryantii, dan Lactobasilus ruminus yang ada di dalam saluran pencernaan ikan. Hal ini sesuai dengan pendapat Mansyur et al. (2008), menyatakan bahwa penambahan probiotik pada pakan dapat menurunkan karbohidrat, tetapi dengan semakin tingginya dosis probiotik yang diberikan pada pakan semakin rendah nilai karbohidratnya, oleh karena itu pemberian probiotik dapat meningkatkan populasi mikroba dalam saluran pencernaan ikan yang dapat memecah karbohidrat menjadi glukosa yaitu enzim amilase.

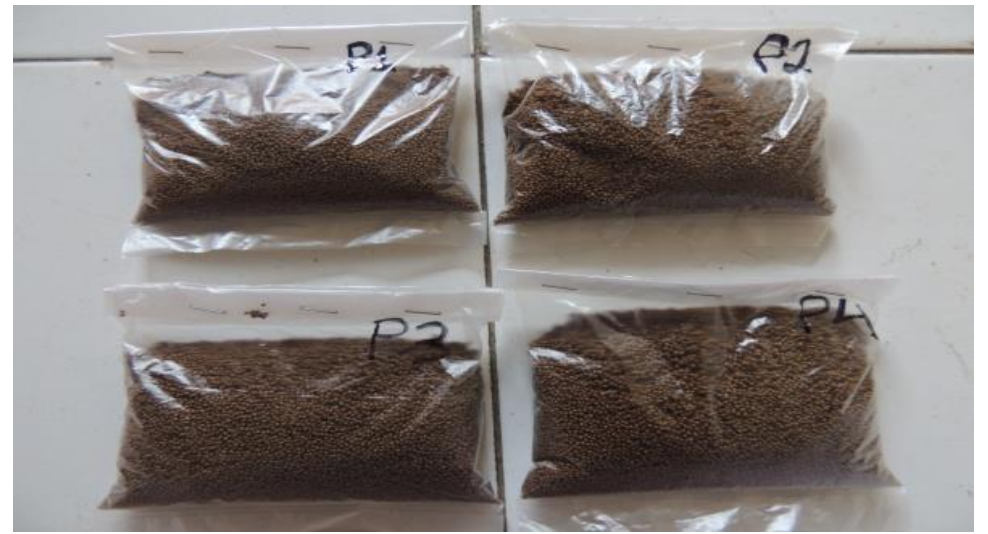

\section{Gambar 5. (P1) Tanpa Probiotik, (P2) Probiotik $5 \mathrm{ml}$ (P3) Probiotik $10 \mathrm{ml}$ (P4) Probiotik $15 \mathrm{ml}$}

Berdasarkan hasil analisa uji proksimat menunjukkan bahwa penambahan probiotik kedalam pakan pellet dapat menurunkan kandungan protein, tetapi semakin tinggi dosis probiotik diberikan maka semakin rendah kangungan proteinnya. Sedangkan pada perlakuan P1 proteinnya lebih tinggi dibandingkan perlakuan lainnya. Hal ini dikarenakan perlakuan P1 tanpa penambahan probiotik pada pakan tidak terdapat bakteri pemecah protein seperti Bacillus licheniformis yang dapat memecah molekul protein menjadi asam amino didalam saluran pencernaan ikan. Oleh karena itu pertumbuhan pada perlakuan P1 lebih rendang dibandingakan perlakuan lainnya. Hal ini diduga penambahan probiotik ke pakan dapat meningkatkan hasil pertumbuhan ikan, karena pakan yang diberi probiotik dapat meningkatkan keberadaan jumlah bakteri yang masuk ke dalam saluran pencernaan dan hidup di dalamnya. Hal ini sesuai dengan pendapat Jusadi et al. (2015), menyatakan bahwa Bacillus merupakan bakteri proteolitik yang dapat menguraikan protein menjadi asam amino. Berdasarkan hasil analisa uji proksimat menunjukkan bahwa kadar air pada perlakuan P1 tanpa pemberian probiotik hasilnya lebih rendah dibandingkan dengan perlakuan lainnya. Sedangkan kadar air pada pakan yang diberi probiotik hasilnya lebih tinggi, oleh karena itu penambahan probiotik dapat menaikkan kadar air. Menurut Sularso (2007), air berperan untuk menstabilkan suhu tubuh, membawa zat gizi dan sisa metabolisme. Kadar air pada pakan pellet yang belum di campurkan probiotik yaitu $9,88 \%$ dan pakan pellet yang telah di campurkan probiotik $5 \mathrm{ml}$ menghasilkan kadar air $18,81 \%$, serta pakan pellet yang dicampurkan probiotik $10 \mathrm{ml}$ menghasilkan kadar air lebih rendah yaitu $11,52 \%$, dan pakan pellet yang dicampurkan probiotik $15 \mathrm{ml}$ menghasilkan kadar air 12,53\%.

Berdasarkan hasil analisa uji proksimat menunjukkan bahwa kadar abu pada pakan pellet yang belum di campurkan probiotik yaitu 8,93\% dan pakan pellet yang telah di campurkan probiotik $5 \mathrm{ml}$ menghasilkan kadar abu 8,78\%, serta pakan pellet yang dicampurkan probiotik $10 \mathrm{ml}$ menghasilkan kadar abu lebih rendah yaitu 8,68\%, dan pakan pellet yang dicampurkan probiotik $15 \mathrm{ml}$ menghasilkan 
kadar abu yaitu 9,37\%. Dari hasil data tersebut menunjukkan bahwa kadar abu yang dihasilkan pada setiap perlakuan tidak berbeda jauh, hal ini disebabkan pemberian probiotik dan dosis yang berbeda. Menurut Mansyur et al. (2008), menyatakan bahwa penambahan probiotik kedalam pakan dapat menurun kan kadar abu dan karbohidrat, tetapi semakin tingginya dosis probiotik maka semakin rendah Berdasarkan hasil analisa uji proksimat menunjukkan bahwa penambahan probiotik dengan dosis 10 ml (P3) pada kadar lemak lebih tinggi dibandingkan dengan perlakuan lainnya, oleh karena itu dosis 10 $\mathrm{ml}$ bisa dibilang dosis yang paling optimal dalam pemecahan lemak. Hal ini diduga penambahan probiotik pada pakan dapat meningkatkan populasi bakteri pemecah lemak yaitu hemiselulosa. Menurut Mutjiman (2002), Kandungan lemak yang berlebihan padapakan akan mempengaruhi mutu pakan, yaitu mudah mengalami oksidasi dan menghasilkan bau tengik. Ikan yang banyak mengonsumsi lemak juga akan mengalami penimbunan lemak pada dinding rongga abdominal dan usus (visceral) sehingga terjadi gejala liver lipid degeneration). Kerusakan lain akibat kelebihan lemak adalah kerusakan pada ginjal, edema, dan anemia yang dapat menimbulkan kematian (Kordi, 2010).

\subsection{Kualitas Air}

Pengamatan kualitas air yang dilakukan selama penelitian meliputi $\mathrm{pH}$, suhu, oksigen (DO), dan Amonia (NH3). Secara keseluruhan kisaran parameter kualitas air tersebut masih berada dalam kisaran normal dan layak bagi kehidupan ikan. Hasil kisaran pengamatan kualitas air selama penelitian pada Tabel 10.

Tabel 10. Parameter Kualitas Air Selama Penelitian

\begin{tabular}{ccccc}
\hline Parameter & \multicolumn{4}{c}{ Perlakuan } \\
\cline { 2 - 5 } & $\mathbf{P 1}$ & $\mathbf{P 2}$ & $\mathbf{P 3}$ & $\mathbf{P 4}$ \\
\hline $\mathrm{pH}$ & $6,5-7,0$ & $6,8-7,4$ & $6,6-7,2$ & $6,5-7,0$ \\
$\mathrm{DO}(\mathrm{mg} / \mathrm{L})$ & $2,50-3,55$ & $2,70-3,67$ & $2,50-3,24$ & $2,00-3,13$ \\
Suhu $(\mathrm{C})$ & $27-31$ & $27-31$ & $27-31$ & $27-31$ \\
Amonia(mg/L) & $0,09-2,34$ & $0,08-1,19$ & $0,11-1,12$ & $0,14-2,38$ \\
\hline
\end{tabular}

Berdasarkan pengamatan kualitas air yang dilakukan selama penelitian meliputi $\mathrm{pH}$, suhu, oksigen (DO), dan amoniak ( $\mathrm{NH}_{3}$ ). Pengamatan $\mathrm{pH}$ air selama penelitian Ikan Patin Siam (Pangasius hypophthalmus) berkisar antara 6,5-7,5. Hal ini sesuai dengan (SNI 64833,2002) dimana kisaran pH untuk pemelihara ikan patin yaitu 5,5-8,5. Menurut Kordi \& Tancung (2007), mengatakan derajat keasaman air yang cocok untuk Ikan patin siam (Pangasius hypophthalmus) adalah 6,5-9,0, untuk pertumbuhan optimalnya terjadi pada $\mathrm{pH}$ 7-8,5. Dari hasil pengukuran $\mathrm{pH}$ selama penelitian menunjukkan bahwa nilai pH pada masing-masing perlakuan sudah optimal untuk pertumbuhan dan kelangsungan hidup ikan Patin Siam (Pangasius hypophthalmus) hal ini dikarenakan selama penelitian air dalam kolam tidak menunjukan sifat asam maupun basah yang dapat mengganggu kehidupan ikan serta air pada kolam selalu dibersihkan dengan cara penyiponan untuk membuang sisa-sisa kotoran agar pH tetap normal. Menurut Kordi \& Tancung (2007), menyatakan bahwa pH yag bersifat asam mengakibatkan terganggunya proses metabolisme ikan, selera makan ikan akan berkurang dan ikan mudah terserang penyakit, serta $\mathrm{pH}$ yang bersifat basah menyebabkan meningkatnya kandungan amonia sehingga dapat mengganggu kehidupan ikan.

Suhu air selama penelitian ikan Patin Siam (Pangasius hypophthalmus) pada setiap perlakuan berkisar antara $27^{\circ} \mathrm{C}-31^{\circ} \mathrm{C}$. Kisaran suhu tersebut merupakan kisaran yang sangat optimal untuk pertumbuhan ikan dimana menurut Sularto (2007), menyatakan bahwa suhu yang optimal dalam pemeliharaan ikan patin yaitu berkisar $27^{\circ} \mathrm{C}-32^{\circ} \mathrm{C}$. Hal ini juga diperkuat oleh Effendie (2002), bahwa suhu yang optimum bagi ikan patin berkisar antara $26^{\circ} \mathrm{C}-32^{\circ} \mathrm{C}$. Hasil Pengukuran suhu selama penelitian masih dalam kisaran yang optimal karena suhu dapat meningkatkan laju metabolisme dalam tubuh yang membuat tingkat kelangsungan hidup ikan Patin Siam (Pangasius hypophthalmus) selama penelitian memiliki nilai yang lebih baik pada setiap perlakuan. Menurut Kordi \& Tancung (2007), suhu 
yang optimal dapat mempengaruhi metabolisme organisme biota budidaya. Hal ini juga diperkuat oleh Sitanggang (2014), menyatakan bahwa Suhu air normal adalah suhu air yang dapat memungkinkan makhluk hidup dapat melakukan metabolisme dan berkembangbiak.

Oksigen terlarut selama penelitian masih dalam batas minimal untuk kelangsungan hidup ikan dimana selama penelitian nilai dari oksigen terlarut berkisar 2,00 sampai dengan 3,67, dan nilai tertinggi terdapat pada perlakuan P2 yaitu 2,70 - 3,67, sedangkan yang terendah terdapat pada perlakuan P4 yaitu berkisar 2,00-3,13. Sesuai dengan pernyataan Salmin (2005), kandungan oksigen terlarut minimum adalah 2 ppm dalam keadaan normal dan tidak tercemar oleh senyawa beracun menurut $(\mathrm{SNI} 64833,2002)$ menyatakan kandungan oksigen terlarut untuk ikan patin berkisar > 4 ppm. Masih minimumnya nilai oksigen terlarut pada pemeliharaan kemungkinan disebabkan oleh pemasangan aerasi yang kurang tepat karena dalam pemasangan aerasi terkadang kederasan dan juga terkadang kekecilan sehingga dapat mempengaruhi oksigen di dalam air. Menurut Sari et al. (2015), menyatakan bahwa kecilnya nilai oksigen terlarut disebabkan oleh proses aerasi yang kurang tepat karena besar kecilnya aerasi akan berpengaruh terhadap banyak sedikitnya oksigen dalam air.

Nilai amonia selama penelitian menunjukkan nilai yang sudah cukup optimal untuk pertumbuhan ikan patin siam (Pangasius hypophthalmus) dimana nilai amonia pada masing- masing perlakuan berkisar antara 0,08-2,38. Hal ini sesuai pendapat Sularto, (2007), menyatakan bahwa konsentrasi amonia terlarut yang baik untuk kelangsungan hidup ikan adalah berkisar antara 0,04-3,01 ppm. Hasil pengukuran kadar amonia menunjukkan nilai amonia pada setiap perlakuan masih dalam kisaran yang cukup optimal untuk kelangsungan hidup ikan patin. Masih cukup optimalnya nilai amonia diduga selama penelitian air berubah menjadi keruh karena terdapat sisa-sisa pakan dan kotoran ikan yang mengendap. Dimana menurut Agustono et al. (2014), menyatakan bahwa sumber amonia didalam air dapat dipengaruhi oleh sisa-sisa pakan dan kotoran ikan. Hal ini juga diperkuat oleh Kordi dan Tancung, (2007) yang menyataka kadar amonia yang terdapat dalam air umumnya merupakan hasil dari metabolisme ikan berupa kotoran ikan (Feces), Walaupun selama penelitian terdapat sisa-sisa pakan dan kotoran ikan yang mengendap didasar air akan tetepi jumlahnya tidak terlalu banyak dan dapat diatasi langsung dengan cara penyiponan air yang rutin sehingga tidak menyebabkan kadar amonia yang terlalu tinggi.

\section{Kesimpulan}

Berdasarkan hasil penelitian yang telah dilakukan, dapat disimpulkan bahwa: a) berdasarkan hasil penelitian menunjukkan bahwa perlakuan pemberian probiotik $5 \mathrm{ml}$ (P2) memberikan hasil yang lebih baik terhadap parameter pertumbuhan berat rata-rata ikan patin siam (Pangasius hypophthalmus) seberat 7,85 gram serta pertumbuhan panjang rata-rata ikan Patin Siam (Pangassius hypophthalmus) terbaik sepanjang $6,30 \mathrm{~cm}$; b) tingkat kelangsungan hidup ikan Patin Siam (Pangasius hypophthalmus) selama penelitian menunjukkan nilai yang terbaik terdapat pada perlakuan P2 yaitu 97,33\%; c) pemberian pakan selama penelitian menghasilkan konversi pakan (FCR) terendah terdapat pada perlakuan $\mathrm{P} 2$ yaitu 0,65 .

Berdasarkan hasil pemeliharaan, maka disarankan pemberian dosis probiotik $5 \mathrm{ml}$ untuk memperoleh laju pertumbuhan yang baik. Untuk mendapatkan hasil kelangsungan hidup yang optimal, maka disarankan untuk menggunakan probiotik dengan dosis $5 \mathrm{ml}$. Berdasarkan hasil pemeliharaan, maka disarankan menggunakan probitik $5 \mathrm{ml}$ dapat menghasilkan konversi pakan yang optimal.

\section{Daftar Pustaka}

[BSN] Badan Standarisasi Nasional. (2000). Standar Produksi Benih Ikan Patin Siam. Standar Nasional Indonesia. 01-6483.4-2000.

[SNI] Standar Nasional Indonesia 01- 6463.3. (2002). Produksi Induk Ikan Patin Siam (Pangasius hypophthalmus) kelas Sebar. Badan Standardisasi Nasional. 1 - $6 \mathrm{hlm}$. 
Abdullah. (2007). Pengaruh Penambahan Probiotik EM-4 dalam Pakan Terhadap Pertumbuhan FCR dan Sintasan Ikan Gurami (Osphronemus gouramy). Department of fisheries.

Affandi, R., D. S. Sjafe'i, M. F. Rahardjo, \& Sulistiono. (2004). Fisiologi Ikan Pencernaan dan Penyerapan Makanan. Tesis. Institut Pertanian Bogor. Bogor.

Agustono. (2014). Sustitusi Tepung Kedelai dengan Tepung Biji koro Pedang (Canavalia ensiformis) terhadap Pertmbuhan,Survival Rate dan Efisiensi Pakan Ikan Nila Merah. Jurnal IImiah Perikanan dan Kelautan. 6 (1) : 1-8.

Ahmadi, H. (2012). Pemberian Probiotik dalam Pakan terhadap Pertumbuhan Lele Sangkuriang (Clarias gariepinus) Pada Pendederan II. Jurnal Perikanan dan Kelautan. 8(1):52-57.

Artarizqi, A. T. (2012). Kolaborasi Mikroba MA-11 Super. Htm. Dalam Jurnal Kurniawan, H. N. A., Kurmalaningsih, S., Febrianto, A. Pengaruh Penambahan Konsentrasi Microbakter Alfaafa 11 (MA-11) terhadap Pupuk Kompos. Universitas Brawijaya Press. Malang 65145.

Effendi, H. (2003). Telaah Kualitas Air : Bagi Pengelolaan Sumber Daya dan Lingkungan Perairan. Kanasius. Yogyakarta.

Hanafiah, K. A. (2011). Rancangan Percobaan : Teori dan Aplikasi. Fakultas Pertanian. Universitas Sriwijaya. Raja Grafindo Persada. Jakarta.

Haryanti, G. N. Permana, S. B. Moria, N. A. Giri, \& K. Sugama. (2002). Penggnaan Bakteri Probiotik Alteromonas sp. BY-9 dalam Pemeliharaan Larva Udang melalui Pakan Alami dan Buatan. Jurnal Penelitian Perikanan indonesia, 5(8):55-66.

Irianto, A. (2003). Probiotik Akuakultur. Gadjah Mada University Press. Yogyakarta. 125 p.

Jusadi, D., E. Gandara, \& I. Mokoginta. (2004). Pengaruh Penambahan Probiotik Bacillus sp. pada pakan komersil terhadap Konversi Pakan Dan Pertumbuhan Ikan Patin (Pangasius Hypoptalmus). Jurnal Akuakultur Indonesia, 3(1):15-18.

Kordi, K. M. G. H. (2010). Budidaya Ikan Patin Biologi, Pembenihan dan Pembesaran. Yayasan Pustaka Nusantara. Yogyakarta.

Kordi, M.G.H. K, \& Tancung. B. A. (2007). Pengelolaan Kualitas Air dalam Budidaysa Perairan. Penerbit Rineka Citra. Jakarta. $208 \mathrm{hlm}$.

Mulyadi, A E. (2011). Pengaruh Pemberian Probiotik Pada Pakan Komersil Terhadap Laju Pertumbuhan Benih Ikan Patin Siam (Pangasius hypoptalmus). Skripsi. Fakultas Perikanan dan Ilmu Kelautan. Universitas Pedjadjaran. Jatinangor.

Mutjiman, A. (2002). Makanan Ikan Penebar Swadaya. Gramedia. Jakarta. 100-151 hlm.

Sahwan, F. (2004). Pakan Ikan dan Udang: Formulasi, Pembuatan, Analisa Ekonomi. Penebar Swadaya. Jakarta.

Sari. A. L. S. (2015). Pertumbuhan dan Rasio Konversi Pakan Ikan Nila (Oreochromis nilotikus) dengan penambahan Probiotik. Jurnal Bioteknologi. 12 (1): 16-21.

Sitanggang, D. L. (2014). Laju Perttmbuhan Populasi Ikan Bawal Air Tawar (Colossoma macropomum, cuvier.) dengan Pemberian Jenis Pakan yang berbeda. Skripsi. Fakultas Matematika dan IImu Pengetahuan Alam. Universitas Sumatera Utara. Medan.

Sularto. (2007). Petunjuk Teknis Pembenihan Ikan Patin. Loka Riset Pemuliaan dan Teknologi Budidaya Perikanan Air Tawar. Amafard Press. Subang.

Sunafik. (2000). Pengaruh Campuran Dedak dan Ransum Komersil terhadap Pertambahan Berat Ayam Buras Umur 4-8 Minggu. Laporan Penelitian. Jurusan Peternakan Fakultas Pertanian. Universitas Islam Kalimantan. Banjarmasin.

Wijayanti, M. Nofyan. E, \& Handayani. I. (2014). Optimasi Tingkat Pemberian Pakan Buatan terhadap Pertumbuhan dan Kelangsunga Hidup Ikan Patin Jambal (Pangasius djambal). Jurnal Akuakkultur Rawa Indonesia, 2 (2) : 175-187.

Yulisman \& Sasanti, D.A. (2012). Pertumbuhan dan Kelangsungan Hidup Benih Ikan Gabus (Channa striata) yang diberikan Pakan Buatan Berbahan Baku Tepung Keong Emas (Pomacea sp). Jurnal Lahan Suboptimal. 1 (2) : 158-162. 